\title{
Flagellate Hyperpigmentation Following Treatment with Low-Dose Bleomycine: Report of two cases
}

\section{Düşük Doz Bleomisin ile Tedaviyi Takiben Flajella Benzeri Hiperpigmentasyon: İki Vaka Raporu}

\author{
Suna Çokmert ${ }^{1}$, Lütfiye Demir ${ }^{2}$, Murat Akyol ${ }^{3}$ \\ ${ }^{1}$ Kent Hastanesi, Tıbbi Onkoloji, İzmir, Türkiye \\ ${ }^{2}$ Aydın Devlet Hastanesi, Tıbbi Onkoloji, Aydın, Türkiye \\ ${ }^{3}$ Katip Çelebi Üniversitesi Atatürk Eğitim Ve Araştırma Hastanesi, Tıbbi Onkoloji, İzmir, Türkiye
}

Dergiye Ulaşma Tarihi:20/01/2015 Dergiye Kabul Tarihi:28/05/2015 Doi: 10.5505/AOT.2015.05706

\section{ÖZET}

Bleomisin'in mukokutanöz yan etkileri, 100 U'den daha yüksek kümülatif dozları alan hastalarda yaygındır. Flagella benzeri hiperpigmentasyon bleomisin kullanımının neden olduğu, vakaların yaklaşık \% 8-20'sinde görülen ilginç bir cilt reaksiyonudur. Mekanizması bilinmemektedir. Tanı karakteristik klinik görünüme dayanmaktadır. Hiperpigmente cilt lezyonlarının histolojik incelemesi, bazal keratinositlerde artmış melanin içeriğini ortaya koymaktadır. Hafif vakalar antihistaminiklere ve/veya sistemik steroide yanıt verir fakat birçok vakada ilacın kesilmesi gerekebilir. Biz rölatif olarak daha düşük (kümülatif dozlar 30 ve $38 \mathrm{U}$ ) dozlarla bleomisin kaynaklı flagella benzeri hiperpigmentasyonu olan 2 vaka sunuyoruz. Bleomisin kullanan hastalarda hiç de nadir olmayan bu komplikasyonu klinisyenler akılda bulundurmalıdırlar.

Anahtar Kelimeler: Hiperpigmentasyon, Bileomisin, Cilt

\begin{abstract}
Mucocutaneus side effects of bleomycin therapy are common in patients receiving cumulative doses greater than $100 \mathrm{U}(100 \mathrm{mg})$. Flagellate hyperpigmentation is an interesting cutaneus reaction caused by bleomycin use, and is seen in about $8-20 \%$ of cases. The mechanism is unknown. Diagnosis is based on its characteristic clinical appearance. Histological examination of hyperpigmented skin lesions has demonstrated increased melanin content in basal keratinocytes. It has been suggested that mild cases may respond to antihistamines and / or systemic steroids, but in many cases discontinuation of the drug may be necessary. We present two patients (cumulative doses of 30 and $38 \mathrm{U}$ ) that developed bleomycin-induced flagellate hyperpigmentation with relatively low doses. Because the condition is not uncommon in patients who are using this drug, the clinician should be mindful of this complication.
\end{abstract}

Key words: Hyperpigmentation, Bleomycin, Skin

\section{Introduction}

Flagellate hyperpigmentation $(\mathrm{FH})$ is reported as a rare cutaneous complication following bleomycin therapy (1). It occurs in $8-20 \%$ of the patients undergone bleomycin treatment, and its mechanism of causing the complication stands unknown (2). Mostly, the complication is considered to happen dose-dependent and generally occurs when the cumulative dose is between 100 and $300 \mathrm{U}$ (3). We, here, present two patients who developed $\mathrm{FH}$ after receiving low dose (30 and $38 \mathrm{U}$ ) of bleomycin treatment.

\section{Case I}

A 78-year-old man, diagnosed with stage III lymphocyte-rich Hodgkin's lymphoma, was started on chemotherapy with adriamycin, bleomycin, vinblastine, and dacarbazine (ABVD). Ten days after the second cycle of chemotherapy (cumulative dose of bleomycin at $38 \mathrm{U})$, some pruritic, linear and erythematous lesions developed on his knees, shoulders, and upper chest (Figure 1). The patient was treated with an intravenous antihistamine and methylprednisolone $(16 \mathrm{mg}$ for 2 days), which temporarily reduced the erythema and relieved the itching problem. However, the streaky erythematous lesions progressed over the course of several days as 
his pruritus relapsed (Figure 2). Furthermore, increased pigmentation developed in the lesions (Figure 3). Skin biopsy specimens obtained from erythematous lesions and pigmented areas showed nonspecific eosinophilia and increased pigmentation in the basal layer. Thus, the final diagnosis was flagellate pigmentation caused by bleomycin use. A dermatologic consultation resulted in a course of prednisone (60 mg for 5 days, $40 \mathrm{mg}$ for 5 days, and $20 \mathrm{mg}$ for 5 days), which improved the pruritic erythematous lesions. Although bleomycin was omitted, the eruptions recurred after the third chemotherapy cycle. The remaining treatments were performed without bleomycin. Areas showed hyperpigmentation in the patient persisted for about 6 months from the beginning of the treatment, and mild pruritus and erythema recurred intermittently. In a follow-up visit at 12 months, the hyperpigmented lesions had disappeared.

\section{Case II}

A 22-year-old male with testicular embryonal carcinoma was started on a 3-week course of a combination chemotherapy with bleomycin, etoposide, and cisplatin (BEP). Seven days after his first course of bleomycin therapy (cumulative dose of bleomycin at $30 \mathrm{U}$ ), he developed a mildly itchy, linear, and flagellate hyperpigmentation over the neck, shoulders, and upper trunk (Figure 4), without showing any erythema or scaling. Antihistamines were given to reduce pruritus. Histological examination was not performed. Bleomycin use was omitted, but the combination chemotherapy including etoposide and cisplatin was continued. While the pruritus slowly resolved after the discontinuation of bleomycin, FH remained for ten months.
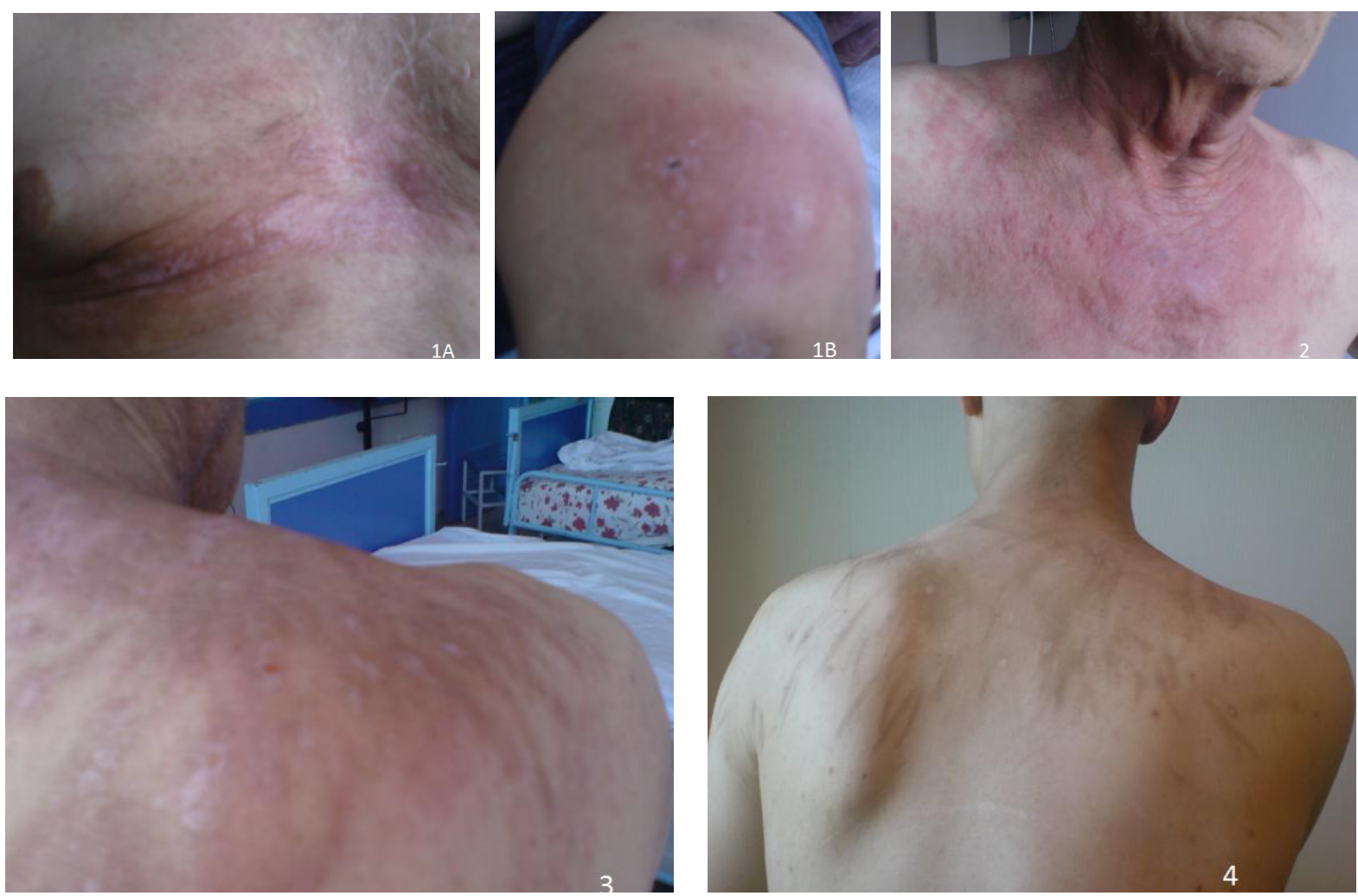

Figure 1: Flagellate erythema on the upper back, chest and knee in Case 1

Figure 2: Rash on upper chest showing characteristic flagellate urticated erythema in Case 1.

Figure 3: Linear, streaked hyperpigmentation over shoulder and neck in Case 1.

Figure 4: Linear, flagellate hyperpigmentation over his trunk in Case 2 


\section{Discussion}

Bleomycin is an antineoplastic antibiotic, isolated from Streptomyces verticillus $(1,2,3)$. It is widely used in the treatment of malignancies such as lymphomas, germ cell tumors, and squamous cell carcinoma (4). At low doses, it inhibits mitosis; however at higher concentrations, it exhibits strong cytostatic activity by blocking the DNA uptake of thymidine in the S-phase of the cell cycle $(4,5)$. Fifty percent of bleomycin is inactivated by an aminohydrolase. Bleomycin-induced toxicity predominantly affects the lungs and skin due to the low levels of hydrolase in these tissues (2-5).

Mucocutaneous side effects of bleomycin are common, and include stomatitis, ulcers, erythematous and bullous lesions, sclerosis, nail changes, digital gangrene, Raynaud's phenomenon, and hyperkeratosis $(5,6)$. $\mathrm{FH}$ is one of the most interesting side effects, and it may occur in $8-20 \%$ of patients who receive bleomycin treatment $(4,6)$. Diagnosis is based on the characteristic clinical appearance of skin lesions. Lesions are usually seen on the upper trunk and limbs and may be associated with pruritus $(2,4,6)$. It can be said that hyperpigmented streaks are generally localized on areas of pressure in linear, or streaked (7). Occasionally, there are erythematous macules or rash with linear configurations on the skin. The exact mechanism of this skin's reaction is not clearly understood. Proposed mechanisms include localized increases in melanogenesis, pigmentary incontinence secondary to inflammation, alterations in normal pigmentation patterns, and induction of neutrophilic eccrine hidradenitis (8-11).

Flagellate erythema and subsequent hyperpigmentation are not associated with the other medications (adriamycin, vinblastine, dacarbazine, etoposide, and cisplatin) administered in our cases. Because, FH has not been described with the other drugs used in the ABVD or BEP regimens. However, case reports describing the development of FH after the use of other medication including bendamustine and docetaxel are available in the literature $(12,13)$.

FH may occur within 9 weeks after administration of bleomycin (14). Lesions in Case I emerged within about 3 weeks after administration of bleomycin, while in Case II, they appeared within one week. The time of occurrence (early or late) may be accepted as a result of age-related drug metabolism velocity and rate.

It is reported that $\mathrm{FH}$ can manifest after bleomycin dosages ranging from $5 \mathrm{U}$ up to 465 $\mathrm{U}$ (15). Yaris et al. reported a child patient undergone treatment with such a low dose as 5 $\mathrm{U}$, with the parental consent (16). The linear or streaked pigmentation usually develops after a cumulative dose between 100-300 $\mathrm{U}$ of bleomycin $(6,17)$, whereas considering our cases the cumulative doses were $38 \mathrm{U}$ and 30 $\mathrm{U}$. There are only 17 adult cases of $\mathrm{FH}$ following treatment with low-dose bleomycin (Table 1) $(2,4,6,8,9,14,15,17-22,25-27)$. It is observed that the majority of patients developing FH within 7 days of administration of bleomycin were young adults, even the dose of bleomycin was between 5-30 U. In our patient, who received a relatively higher dose (Case I, $38 \mathrm{U}$ ), FH manifested 21 days after the administration of bleomycin, besides, the patient was of advanced age. The literature also describes $\mathrm{FH}$ after the administration of bleomycin in terms of intralesional (14 U bleomycin) (23) and intrapleural (30 U bleomycin) (24). In the case reported by Abess et al., the patient developed generalized pruritus and urticaria within 1 hour of the bleomycin (14 U) injection, developing erythematous streaks on the trunk, which became hyper-pigmented (23). Also, considering the reported case of FernandezObregon et al., pigmented flagellate streaks developed on the arms and chest one month after bleomycin (30 U) administration (24). The skin reactions due to bleomycin were independent of the route of administration and dosage, and there were a preponderance of Hodgkin lymphoma. Furthermore, according to our evaluation, the complication occurs in a shorter time at lower doses vice versa (Table 1).

A specific treatment for $\mathrm{FH}$ is not available. This skin reaction is reversible after discontinuation of bleomycin, and reintroduction of the drug may cause recurrence of the reaction $(3,25,26)$. But, in patient who received ABVD therapy (Case I), without bleomycin in the third chemotherapy cycle, the eruptions recurred. In the literature, a similar case was explained by the recall phenomenon (27). In Case II, the hyperpigmentation 
persisted for an extended period of time (about 10 months). It is reported in the literature that the lesions typically resolve within 6-8 months after the withdrawal of bleomycin $(3,26,27)$. The treatment of FH is generally symptomatic, primarily managing the pruritus. Minor trauma to the skin from scratching is thought to increase blood flow and cause local accumulation of bleomycin, resulting in hyperpigmentation. Therefore, the treatment of FH includes topical or systemic corticosteroids and antihistamines (27).
In summary, it can be said that $\mathrm{FH}$ is an interesting cutaneous complication after bleomycin therapy, occurring even at lower doses. This cutaneous reaction is not observed in all cases that receive bleomycin and, as stated in the literature, it can be observed even after very low doses. It can be suggested that this skin reaction isn't dose-dependent and that individual characteristics (e.g. age, drug metabolism rate in the liver, level of hydrolase, etc.) may play a role in the etiology of FH. Additional studies are required.

Table 1: The reported cases of low-dose bleomycin-induced flagellate hyperpigmentation

\begin{tabular}{|c|c|c|c|c|}
\hline Literature and Ref. no & $\begin{array}{c}\text { Time to } \\
\text { development } \\
\text { of FH after } \\
\text { start of } \\
\text { bleomycin }\end{array}$ & $\begin{array}{l}\text { Total cumulative } \\
\text { dose of bleomycin }\end{array}$ & Age & Diagnosis \\
\hline Chen et al., 2007 & $7 \mathrm{~d}$ & $\begin{array}{c}10 \mathrm{mg} / \mathrm{m}^{2}(\mathrm{NR}, \max \\
20 \mathrm{mg})\end{array}$ & 25 & Hodgkin's disease \\
\hline Biswas et al., 2013 & $4 \mathrm{~d}$ & $\begin{array}{c}10 \mathrm{mg} / \mathrm{m}^{2}(\mathrm{NR}, \max \\
20 \mathrm{mg})\end{array}$ & 22 & Hodgkin's disease \\
\hline Lindae et al., 1987 & $30 \mathrm{~d}$ & $\begin{array}{c}10 \mathrm{mg} / \mathrm{m}^{2}(\mathrm{NR}, \max \\
20 \mathrm{mg})\end{array}$ & 43 & Hodgkin's disease \\
\hline Polla et al., 1986 & $1 \mathrm{~d}$ & $15 \mathrm{mg}$ & 51 & For diagnosis \\
\hline Cortina et al., 1990 & $1 \mathrm{~d}$ & $\begin{array}{c}10 \mathrm{mg} / \mathrm{m}^{2}(\mathrm{NR}, \max \\
20 \mathrm{mg})\end{array}$ & 22 & Hodgkin's disease \\
\hline Rademaker et al.,1987 (14) & $7 \mathrm{~d}$ & $30 \mathrm{mg}$ & 55 & Nasopharynx ca \\
\hline Rademaker et al.,1987 (14) & $7 \mathrm{~d}$ & $30 \mathrm{mg}$ & 67 & $\begin{array}{l}\text { Tongue squamous } \\
\text { cell ca }\end{array}$ \\
\hline Ziemer et al., 2011 & $4 \mathrm{~d}$ & $30 \mathrm{mg}$ & 47 & Testicular seminoma \\
\hline Khaliq et al., 2011 & $2 \mathrm{~d}$ & $30 \mathrm{mg}$ & 31 & Testicular seminoma \\
\hline Mikhail et al., 2005 & $2 \mathrm{~d}$ & $15 \mathrm{mg}$ & 29 & Kaposi's sarcoma \\
\hline Arseculeratne et al.,2007 (19) & $3 \mathrm{~d}$ & $\begin{array}{c}10 \mathrm{mg} / \mathrm{m}^{2}(\mathrm{NR}, \max \\
20 \mathrm{mg})\end{array}$ & 45 & Hodgkin's disease \\
\hline Miori et al.,1990 & $\begin{array}{l}\text { After a few } \\
\text { hours }\end{array}$ & $15 \mathrm{mg}$ & 25 & Hodgkin's disease \\
\hline Schuler et al., 1984 & $1 \mathrm{~d}$ & $5 \mathrm{mg}$ & NA & Hodgkin's disease \\
\hline Vignini et al.,1989 & $1 \mathrm{~d}$ & $15 \mathrm{mg}$ & 25 & Hodgkin's disease \\
\hline Vicente et al., 1990 & NA & $15 \mathrm{mg}$ & NA & Hodgkin's disease \\
\hline Mowad et al., 1994 & $4 \mathrm{~d}$ & $15 \mathrm{mg}$ & 36 & Hodgkin's disease \\
\hline Todkill D et al., 2008 & $7 \mathrm{~d}$ & $\begin{array}{c}10 \mathrm{mg} / \mathrm{m}^{2}(\mathrm{NR}, \max \\
20 \mathrm{mg})\end{array}$ & 48 & Hodgkin's disease \\
\hline Present Case 1 & $21 \mathrm{~d}$ & $38 \mathrm{mg}$ & 78 & Hodgkin's disease \\
\hline Present Case 2 & $7 \mathrm{~d}$ & $30 \mathrm{mg}$ & 22 & Testis embrional ca \\
\hline
\end{tabular}

$\mathrm{NR}=$ Not reported, $\mathrm{NA}=$ Not available, $\mathrm{FH}=$ Flagellate hyperpigmentation, $\mathrm{D}=$ day

Disclosures: Conflict of interest: none. Written consents were obtained from patients. 


\section{References:}

1. Remlinger KA. Cutaneous reactions to chemotherapy drugs. The art of consultation. Arch Dermatol. 2003;139(1):77-81.

2. Chen YB, Rahemtullah A, Breeden E, et al. Bleomycin-induced flagellate erythema. J Clin Oncol. 2007;25:898-900.

3. Grynszpan R, Niemeyer-Corbellini JP, Lopes MS et al. Bleomycin-induced flagellate dermatitis. BMJ Case Rep. 2013;27:2013

4. Biswas A, Chaudhari PB, Sharma P et al. Bleomycin induced flagellate erythema: Revisiting a unique complication. J Cancer Res Ther. 2013;9(3):500-3

5. Yamamoto T. Bleomycin and the skin. British Journal of Dermatology. 2006;155(5):869-75

6. Lindae $\mathrm{ML}, \mathrm{Hu} \mathrm{CH}$, Nickoloff BJ. Pruritic erythematous linear plaques on the neck and back. "Flagellate" erythema secondary to bleomycin therapy. Arch Dermatol.1987;123(3): 395-8

7. Nayak N, Friedmann PS, Healy E. Case 2. Bleomycin induced flagellate dermatosis. Clin Exp Dermatol. 2003; 28 (1):105-6

8. Polla BS, Merot Y, Saurat JH, et al. Flagellate pigmentation from bleomycin [letter]. J Am Acad Dermatol. 1986;14 (4):690

9. Cortina P, Garrido JA, Tomas JF, Unamuno P, Armijo M. Flagellate erythema from bleomycin with histopathological findings suggestive of inflammatory oncotaxis. Dermatologica.1990; 180 (2):106-9

10. Tsuji T, Motokazu S. Hyperpigmentation in striae distensae after bleomycin treatment. J Am Acad Dermatol.1993; 28 (3):503-5

11. Al-khenaizan S, Al-berouti B. Flagellate pigmentation: a unique adverse effect of bleomycin therapy. EJD. 2011; 21(1);146

12. Chew L, Chuen VS. Cutaneous reaction associated with weekly docetaxel administration. J Oncol Pharm Pract. 2009;15(1):29-34

13. Mahmoud BH, Eide MJ. Bendamustine-Induced "Flagellate Dermatitis" Dermatology Online Journal. 2012;15;18(11):12

14. Rademaker M, Thomas RH, Meyrick Lowe DG, et al. Linear streaking due to bleomycin. Clin Exp Dermatol. 1987;12 (6):457-9
15. Ziemer M, Goetze S, Juhasz K, et al. Flagellate dermatitis as a bleomycin-specific adverse effect of cytostatic therapy. Am J Clin Dermatol. 2011;12:6876

16. Yaris N, Cakir M, Kalyoncu M, Okten A. Bleomycin Induced hyperpigmentation with yolk sac tumor. Indian J Pediatr. 2007;74:505-6

17. Khaliq W, Antonarakis ES. Flagellate erythema secondary to bleomycin. QJM. 2012;105(9):901

18. Mikhail M, Eichenbaum M, Gerstenfeld E, et al. Simultaneous acral nodular eruption and flagellate erythema caused by bleomycin. J Drugs Dermatol. 2005; 4 (1):81-4

19. Arseculeratne G, Berroeta L, Meiklejohn D, et al. Bleomycin-induced "flagellate dermatitis". Arch Dermatol. 2007;143 (11):1461-2

20. Miori L, Vignini M, Rabbiosi G. Flagellate dermatitis after bleomycin: a histological and immunohistochemical study. Am J Dermatopathol. 1990;12 (6):598-602

21. Schuler G, Aubock J, Huber H. Bleomycin-induced linear hyperpigmentation [in German]. Hautarzt 1984;35 (7):383-6

22. Vignini M, Miori L, Brusamolino E, et al. Linear streaking after bleomycin administration [letter]. Clin Exp Dermatol.1989;14 (3):261

23. Abess A, Keel DM, Graham BS. Flagellate Hyperpigmentation Following Intralesional Bleomycin Treatment of Verruca Plantaris. Arch Dermatol.2003;139(3):337-9.

24. Fernandez-Obregon AC, Hogan KP, Bibro MK. Flagellate pigmentation from intrapleural bleomycin. J Am Acad Dermatol. 1985;13(3):464-8.

25. Vicente MA, Iranzo P, Azon A, Mascaro JM, Grau J. Flagellated pigmentation caused by bleomycin: presentation of 2 cases. Med Cutan Ibero Lat Am.1990;18(2):148-150.

26. Mowad CM, Nguyen TV, Elenitsas R, et al. Bleomycin-induced flagellate dermatitis: a clinical and histopathological review. $\mathrm{Br} \mathrm{J}$ Dermatol. 1994;131:700-2.

27. Todkill D, Taibjee S, Borg A et al. Flagellate erythema due to bleomycin. British Journal of Haematology. 2008;142(6):857 